\section{Realizações e Previsões para o Próximo Ano}

$\mathbf{O}$ Arquivos brasileiros de Endocrunologia e metabologia (ABE\&M) foram lançados em 1951 pela iniciativa pioneira de Waldemar Berardinelli e Thales Martins, encabeçando um grupo de personagens marcantes do cenário científico da época. Além desses fundadores (que publicaram a revista de 1951 a 1955), perfilaram como Editores dos ABE\&M, até 1972, dois outros expoentes da Endocrinologia nacional: Clementino Fraga Filho (1956-1963) e Luiz Carlos Lobo (1964-1972). Nesta época, por razões várias, houve interrupção da circulação dos "Arquivos" por seis anos consecutivos quando, em 1978, o saudoso colega Armando de Aguiar Pupo assumiu perante a SBEM o compromisso de resgatar e relançar a revista. Em sua gestão, de 1978 até 1982, foram publicados os volumes 22 a 25 dos ABE\&M, contendo um número ainda modesto de colaborações científicas, indício de uma sociedade científica que começava a se definir melhor e se estruturar em âmbito nacional. No entanto, o reinício das publicações científicas da SBEM foi um marco auspicioso para a ocasião, antevendo perspectivas de sucesso, embora muitos ainda se lembrem dos percalços enfrentados pelo editor, Dr. Pupo, para conseguir colocar a revista em funcionamento.

Subsequentemente, assumiu a Editoria Antônio R. Chacra, que conduziu a revista de 1983 a 1990 , tendo publicado os oito volumes seguintes (26 a 33), englobando um total de 16 números. Ainda neste período a revista tinha pouca autonomia para se manter e continuava sendo editada com bastante dificuldade, estando sujeita, além das flutuações de colaborações científicas dos colegas, às instáveis condições financeiras da época. Por conta disto, a frequiência e a constância da publicação, bem como a quantidade do material a ser publicado, passou a ser determinado em parte pela editora comercial da época, com vistas à melhor relação custo-beneficio financeiro.

Em final de 1990, Rui Monteiro de Barros Maciel é escolhido pelo Conselho Deliberativo da SBEM para ser Editor-chefe durante o período de 1991 a 1994. Sua gestão caracterizou-se pela revitalização da revista, e por um determinado apelo colaborativo na tentativa de "extrair" material de diversos grupos nas várias instituições de ensino e pesquisa em Endocrinologia e Metabologia do país. Isto permitiu a definição de um novo padrão de editoria, num processo de plena autonomia e maior divulgação da colaboração dos pares. Assim, nestes quatro anos foram publicados 16 números (volumes 35 a 38) que continham uma quantidade maior de material científico inciuindo, rotineiramente, artigos de revisão e discussões de casos em complemento aos artigos originais. Algumas seções foram criadas ("Perspectivas") e muitos artigos passaram a ser encomendados de maneira sistemática. Maior integração, participação e colaboração passaram a ser regras de sua gestão. A partir do volume 37 a revista passou a ser editada diretamente por nós, permitindo certa desvinculação com editoras comerciais.

No final de 1994, meu nome é indicado e aceito pelo Conselho Deliberativo para dar continuidade ao processo de desenvolvimento e apri- editorial

Claudio E. Kater

Editor-Chefe, ABE'SM 
moramento da revista. Assim, assumo o cargo pelo período de 1995 a 98 , tendo publicado até este número os volumes 39 a 42 , contendo 17 números e 6 suplementos. Em 1998, junto com os Editores Associados e Co-Editores, iniciamos uma nova concepção editorial, com ampla reformulação gráfica e editorial da revista e a iniciativa de tornar a publicação bimestral. Embora um pouco arrojada, segundo a visão de alguns assessores, o momento nos pareceu oportuno para oferecer maior espaço e poder dar vazăo a uma já certa demanda reprimida de material.

Na reunião do Conselho Deliberativo da SBEM realizado em Outubro/Novembro de 1998, durante o $23^{\circ}$. Congresso Brasileiro de Endocrinologia e Metabologia (CBEM) em São Paulo, tive a honra de ser reconduzido ao cargo de Editor-chefe por um novo período de quatro anos (1999-2002). Gostaria, neste momento, de agradecer a confiança que me foi depositada mais uma vez, através da ratificação de meu nome, por um grande número de leitores da revista, pela virtual unanimidade dos membros do Conselho Editorial e pela grande maioria dos participantes do Conselho Deliberativo da SBEM.

Existe um plano e um projeto de trabalho que foram definidos desde a época em que eu e Antonio C. Bianco eramos colaboradores com Rui Maciel e que foi adequado e aprimorado ao longo deste anos, buscando elevar a revista a um patamar internacional de qualidade. Sabidamente, o caminho é árduo e tortuoso, mas muito agradável e gratificante. Agora, uma nova perspectiva de sucesso se avizinha, pela possibilidade de trabalharmos de maneira mais integrada com as Sociedades afins (ou irmãs, como queiram): durante este mesmo $23^{\circ} \mathrm{CBEM}$, por iniciativa do Presidente da SBEM, Dr. Thomaz Cruz, reuniram-se representantes da SBD (Sociedade Brasileira de Diabetes), SOBEMOM (Sociedade Brasileira de Estudos do Metabolismo Ósseo e Mineral) e da ABESO (Associação Brasileira para o Estudo da Obesidade) e definiu-se consensualmente que os Arquivos Brasileiros de Endocrinologia e Metabologia torna-se, a partir de agora, o Orgão Oficial de Divulgação Científica não somente da SBEM, mas também da SBD, SOBEMOM e ABESO. Os presidentes dessas Sociedades passam, então, a integrar o Conselho Editorial da revista como Editores Associados.

Acredita-se, desta forma, que os ABE\&M venham a ser tornar o forum das manifestações científicas destas Sociedades e representar o pensamento integra- do de toda uma comunidade de Endocrinologistas e Metabologistas brasileiros. Dado que "a união faz a força", não deveremos encontrar dificuldades em nos firmar cada vez mais como orgão representativo da filosofia destas Sociedades irmãs e de implementar idéias e propostas que, de outra maneira, estariam dispersas e dissociadas do espírito comunitário, característica de nossa Sociedade deste sua fundação.

Espera-se, também, que se possa coibir iniciativas de interesse meramente comercial ou de satisfação de vaidades pessoais menores, pela criação de outras "revistas" específicas ou regionais (ou pela simples tradução de outras revistas internacionais de pequena estatura científica), que detratam as iniciativas de concentração de esforços de nossa revista e desviam a atenção dos associados e do público leitor em geral. Há de chegar o momento em que nossa SBEM, por sua própria iniciativa e contemplando necessidades internas, poderá vir a lançar uma segunda revista com características distintas, mas que deverá adicionar - e não subtrair - informações de qualidade para o benefício cultural de seus associados.

Para terminar, gostaria de agradecer imensamente a todos os nossos revisores que durante este ano ofereceram horas preciosas de seu tempo para nos auxiliar no julgamento de manuscritos, garantindo a melhoria de qualidade tanto na forma como no conteúdo de todo o material publicado na revista. Agradeço aos nossos colaboradores por selecionarem e mesmo priorizarem os $\mathrm{ABE} \& \mathrm{M}$ em detrimento de outras revistas para a publicação de seus manuscritos; sou grato em especial a alguns deles para os quais encomendei artigos de revisão com prazos bastante restritos e aos "editorialistas", que nunca têm mais do que uma semana para encaminhar o material solicitado (e que quase nunca reclamam!). Não posso jamais esquecer dos nossos patrocinadores habituais, parceiros da iniciativa privada que com a garantia da continuidade da colocação de inserções comerciais, tem nos permitido, finalmente, trabalhar com certa folga de caixa, possibilitando melhorarmos o formato da revista e a qualidade da editoração e impressão final. Finalmente, agradeço a todos aqueles que tem, ao longo dos anos, oferecido idéias, sugestões e críticas, além de inúmeras palavras de apoio e incentivo, especialmente nos momentos de desalento.

Desejo a todos um feliz Natal e um 1999 pleno de grandes realizações. 